\title{
The Effects on Financial Leverage and Performance: The IFRS 16
}

\author{
Francesca Magli ${ }^{1}$, Alberto Nobolo ${ }^{1}$, Matteo Ogliari ${ }^{1}$ \\ ${ }^{1}$ University of Milano Bicocca, Italy \\ Correspondence: Francesca Magli, University of Milano Bicocca, Italy.
}

Received: June 19, 2018

doi:10.5539/ibr.v11n8p76

\author{
Accepted: July 10, 2018 \\ Online Published: July 19, 2018 \\ URL: https://doi.org/10.5539/ibr.v11n8p76
}

\begin{abstract}
This paper analyses the potential impacts of the introduction of a new accounting standard, International Financial Reporting Standard 16 (IFRS 16) - Leases, on financial leverage and performance of entities. This new accounting standard was introduced on 13 January 2016, and will become effective on 1 January 2019; it will have material impacts on the financial statements of listed companies adopting IFRS and change the basic principles of the current accounting system. Our aim is to estimate the impacts of the application of IFRS 16 on listed issuers of financial statements and the different impacts that the new standard could have in different activity sectors. This research estimates the effects of IFRS 16 on the ratios of debt/total assets, EBITDA/revenues and debt/equity. The conclusions summarize the effects on entity performance and net financial position. The research shows that in the financial statements of the lessee, there will be important changes. In particular, in the balance sheet, there will be an increase in lease assets, an increase in financial liabilities and a decrease in equity, while in the income statement, there will be an increase in EBITDA and an increase in finance costs. The impact of the application of IFRS 16 will be different depending on the use of operating lease contracts among the different business sectors. Leases are an important and flexible source of financing; listed companies, using IFRS and U.S. GAAP, are estimated to have around US\$ 3.3 trillion in lease commitments. Finally, this study aims to analyse the possible impacts of communication of entities, focusing on alternative performance measures.
\end{abstract}

Keywords: alternative performance measures, IFRS 16, financial leverage, lease, non-GAAP measures, performance

\section{Introduction}

Businesses today have an increasing need to share their financial information; in order to provide clearer and more transparent information and to facilitate the comparison of information with others, companies must adopt the same rules. One of the most important points that increase the effectiveness of financial communication is, in fact, "compliance with all regulatory requirements".

To obtain greater effectiveness of financial communication, the application of an "accounting regulation" is important; Meeks and Meeks (2001), in this regards, use the term "accounting regulation" to refer to financial accounting standard-setting, auditing/assurance and enforcement and refer to the overall system of regulation, as well as, in some of their discussions, to specific standards.

After the US securities acts of 1933/34, Watts and Zimmerman (1986) said that "accounting theorists became more concerned with policy recommendations, they become more normative, so concerned with what should be done, with prescribing how firms should report". In Europe, the rules for financial communication are entrusted to the European Union, which has decided to adopt international accounting standards for the preparation of financial statements. To increase the comparability of the financial information of different companies (in perhaps different countries), the European Union enacted Regulation (EC) No. 1606/2002 of the European Parliament, which requires listed companies to apply the international accounting standards or IAS/IFRS (International Accounting Standards/International Financial Reporting Standards) ${ }^{1}$. In April 2001, the International Accounting Standards Board ("IASB") created the IAS/IFRS. There are IFRS on various financial

\footnotetext{
${ }^{1}$ In Europe and Australia, consolidated financial statements prepared under IFRS have been mandatory for listed companies since January 2005. In other countries, i.e., Germany, listed companies have been permitted to adopt IFRS even before they become mandatory (Brown, 2011)
} 
statement items, including rewriting previous IAS and the implementation of new ones.

On 13 January 2016, the IASB issued a new accounting standard IFRS 16 - Leases, which will become effective 1 January 2019. The introduction of this new accounting standard will have material impacts on the financial statements of listed companies and on those adopting IFRS, changing basic principles of the current accounting system. A lease is a contract, where one party (lessor) allows another (lessee) the right to use an asset for a given period through the payment of a consideration. Even if not explicitly referred to as a lease contract, contracts related to rent, hire and tenancy also meet the definition of "lease contracts".

IFRS 16 provides a new definition of a lease and introduces a control-based criterion for assets ("right of use") to distinguish a lease from a service contract. However, the current standard (IAS 17 Leases) distinguishes lease contracts as operating and finance leases. Currently, lessees usually account for operating leases on an accrual basis (the cost shown in the financial statement is usually equal to the fee paid for the year), similar to the accounting for rents/hires (and services in general), without the recognition of a liability for future payments (lessees should disclose future payment commitments in the notes to the financial statements). However, the accounting for finance leases involves the recognition of an asset in the statement of financial position and the recognition of a liability for future lease payments.

The current accounting standard governing lease agreements, therefore, does not require the recognition of liabilities arising from operating leases in the financial statements. Conversely, IFRS 16 will require the recognition of lease liabilities for payments to be paid to the lessor in the net financial position, which will have a significant impact on capital and financial strength indicators such as key performance indicators ("KPIs") and covenants. The standard setters (i.e., IASB, the most important board for the accounting standards around world and FASB- Financial Accounting Standards Board, the most important board for the accounting standards in the United States, which have been working together on this project for over 10 years) have developed a new accounting model applicable to lessees/tenants, with the goal of recognizing assets and liabilities for rights and obligations arising from lease contracts (with some limited exceptions) regardless of their nature. Undoubtedly, the goal of the new accounting model is to overcome the alleged lack of transparency of the current accounting model, to avoid or reduce structured contracts (structured with the sole purpose of achieving a certain accounting effect) and, ultimately, to improve the comparability of financial statements. For example, consider the case of two airlines, where one owns the aircrafts as property, while the other leases the aircraft under an operating lease. Currently, the assets and liabilities of these two airlines are not comparable, while they will be comparable following the adoption of the new accounting standard, IFRS 16.

At this point, we must provide some perspective about the magnitude of the issue that is the subject of our discussion. In this regard, in 2005, the U.S. Securities and Exchange Commission ("SEC") estimated operating lease commitments not recognized in US financial statements to be approximately US\$ 1.25 trillion, highlighting how companies facing financial troubles have significantly used lease contracts as a source of funding. Similarly, in 2015, the IASB conducted a survey on the potential impact of the new accounting standard on the financial statements of 30,000 listed companies, where approximately 14,000 reported information related to unrecognized operating lease commitments totalling \$ 2.86 trillion. The materiality of their impacts is therefore evident.

The European Financial Reporting Advisory Group ("EFRAG") has the task of promoting European interests, especially in the standard-setting activity carried out by the IASB. The European Commission asked the EFRAG to provide its opinion about the EU endorsement of the new IFRS 16. To express its opinion, the EFRAG commissioned an independent company to perform a study, "Ex ante impact assessment of IFRS 16", which estimated that the introduction of IFRS 16 will increase the liabilities of European listed companies (the banking sector was excluded from this analysis) by approximately 576 billion Euro based on lease information provided in the 2015 financial statements for such companies. Although all entities will be affected by the new standard, those in the airline, retail and travel \& leisure sectors will be the most affected. On 27 March 2017, EFRAG issued a favourable opinion on the endorsement of IFRS 16. In particular, the EFRAG concluded that "[...] IFRS 16 meets the qualitative characteristics of relevance, reliability, comparability and understandability required to support economic decisions and the assessment of stewardship, leads to prudent accounting, and that is not contrary to the true and fair view principle [...]". The EFRAG has recommended the endorsement of IFRS 16 by the European Commission. At the date of this document, endorsement is expected during the fourth quarter of 2017.

Although, as previously mentioned, IFRS 16 will be mandatory from 1 January 2019, it is evident that it is undoubtedly in the interest of the entities to assess the potential impacts of the new standard and to define any 
operational changes that may be required (i.e., lease or buy) involving the appropriate business functions: purchasing, general services, information systems, treasury and legal and corporate affairs.

To provide insights on the potential impacts expected from the introduction of IFRS 16 on the financial statements of Italian issuers, we conducted an empirical study using the disclosures on operating lease commitments reported in the 2016 financial statements of the 384 entities listed on the Italian Stock Exchange. This study is purely indicative, and its scope is limited by the fact that not all the companies provided the disclosures required by IAS 17 on future payment commitments. Similarly, when such disclosures were provided in the financial statements, they may be underestimated (e.g., in a $6+6$-years lease, the current disclosure on commitments includes future lease payments for only the first contractual period, while IFRS 16 requires a more complete evaluation of the contractual term, which might result in a 6 or 12-year lease term). However, despite the aforementioned limits on the completeness of the underlying source of the study, it is worthy of interest for the size of the increased indebtedness that will presumably be shown in future financial statements.

Moreover, we conducted the same empirical study using the disclosures on commitments for operating leases reported in the financial statements as of 31 December 2015, by listed entities on the Italian Stock Exchange. In the 2016 financial statements, we noted both a higher number of issuers providing disclosures on operating lease commitments (from 102 in 2015 to 113 in 2016) and higher amounts disclosed as future undiscounted lease payments (from Euro 171.4 billion in 2015 to Euro 173.6 billion in 2016). Therefore, it is evident that the approaching date of IFRS 16's first application is generating greater awareness and, consequently, more attention to the completeness of the disclosures on issuers' operating leases.

The paper is organized as follows. After the introduction, the first part provides an analysis of theoretical framework, literature review, explanation of the new IFRS 16 and alternative performance measures ("APMs"). The second part covers the methodology, sample and source data, followed by the analysis of the impacts of the application of IFRS 16 on listed issuers financial statements. Finally, we perform some considerations on impacts in connections with the main entities communication tools (i.e., KPIs, APMs) and possible impacts on company transactions.

\section{Theoretical Framework and Literature Review}

Financial communication provided by a company discloses full, timely and relevant information about its financial situation and is an important factor in reducing the cost of capital. Furthermore, it is an important link between the company and its stakeholders, especially investors, and it plays an important role in informing investors, consumers and shareholders about its financial state (Wang, 2013).

\subsection{Theoretical Framework}

The reasons companies want to apply accounting standards depend primarily on the benefits that managers and shareholders can derive from doing so. Several scholars, including Watts and Zimmerman, have studied a theory (Positive Accounting Theory) that is useful in explaining the use of accounting standards (Watts and Zimmerman, 1978, 1979, 1986).

Owing to these two scholars, positive accounting has become an academic accounting theory that helps explain and predict actual practices in accounting. In the Positive Accounting Theory, Watts and Zimmerman claim that "management plays a central role in the determination of standards" and "one function of financial reporting is to constrain management to act in the shareholders' interest". (Watts \& Zimmerman, 1978:113). These two considerations underline how the importance of adopting new and good accounting standards, especially for large companies (as suggested by Watts and Zimmerman), also helps solve classic problems due to the agency theory ${ }^{2}$, i.e., problems related to the difference in interests between shareholders and managers. As Brown states, "Accounting standards are important in a well-developed capital market because they help resolve a serious agency problem. Insiders (managers) are better informed than outsiders (shareholders) about their firm's investment opportunities, how hard they, the managers, will work and the perks they will consume and how well the firm is doing overall. Uniform accounting and auditing standards will be found because they are a relatively low-cost solution to a serious agency problem" (Brown, 2011:270).

Therefore, support for clear and transparent information within the financial statements allows the interests of

\footnotetext{
${ }^{2}$ The agency theory is a theory that explains the relationship between principals and agents in business. The problems that can exist in agency relationships are related to the different and varying interests of the principal and agent when the principal is unable to verify what the agent is actually doing. Agency theory is also concerned with different attitudes towards risk held by the principal and agent (Jensen and Meckling, 1976).
} 
managers to be brought closer to those of shareholders.

The creation of new accounting standards should, therefore, take into account all of these aspects and seek to focus not just on some fundamental features such as:

- higher quality of information (more accurate, comprehensive and timely financial statement information);

- minor difference in the knowledge of information between small investors and professionals (adverse selection);

- greater comparability, eliminating many international differences in accounting standards and standardizing reporting formats;

but primarily seek to increase the benefits for shareholders and obviously for managers (Ball, 2006, Brown, 2011).

Furthermore, higher-quality information, according to Ball, "should reduce both the risk to all investors from owning shares and the risk to less-informed investors due to adverse selection. In theory, it should lead to a reduction in firms' costs of equity capital" (Ball, 2006:11).

Taking into account all of these considerations, it is clear that those who create the accounting standards (i.e., IASB or FASB) are subjected to the pressure of the management and the shareholders of the main large companies that have the goal of maximizing their interests (Watts \& Zimmerman, 1978:112). To meet these needs and increase financial communication, the standard setters decided to introduce a new standard, also in the context of leasing, i.e., the IFRS 16. The reasons for the new IFRS on leases are as follows:

- operating leases are not recognized in the balance sheets of lessees, which affects the comparability of the financial statements of companies operating in the same sector, especially between those that purchase the assets owned and those that use leasing;

- $85 \%$ of leasing contracts are not included in the company balance sheet;

- more than USD 2,000 million will be able to "emerge" in the balance sheets (survey conducted by IASB and FASB in 2012);

- financial statements of entities are not comparable;

- standard setters have noted that the entities with financing problems use operating leases extensively to finance their activities and the increase in debt is not reflected in their financial statements. In particular, standard setters conducted a specific study on the financial statements of entities that had fallen into bankruptcy and noted that in the years before the bankruptcy, they increased the use of operating leases significantly, which gave them the opportunity to hide real indebtedness (FASB and IASB analyses).

\subsection{Literature Review}

Accounting for leases is one of the convergence projects for $\mathrm{IASB}^{3}$ and $\mathrm{FASB}^{4}$. "The objective of the lease project is to develop a standard that establishes the principles that lessees and lessors shall apply to report useful information to users of financial statements about the amount, timing and uncertainty of cash flows arising from a lease. To meet that objective, an entity shall recognize all assets and liabilities arising from a

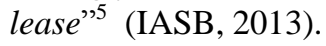

FASB took up accounting for leases as one of its first priorities and devoted a number of staff to lease accounting issues (Monson, 2001:275). For years, users of financial statements, academics and regulators have criticized leasing accounting principles as unnecessarily complex and ineffective in the way they portrayed liabilities arising from leasing contracts in the balance sheet of lessee companies (Monson, 2001).

Many scholars have studied leases (Barone et al., 2014); while some of them have focused on the effect on stock market prices (Ro, 1978, Bowman, 1980), most of them have focused on the analysis of the impact of

\footnotetext{
${ }^{3}$ IASB is the body responsible for issuing international accounting standards around the world.

${ }^{4}$ Established in 1973, the Financial Accounting Standards Board (FASB) is an independent, private sector, not-for-profit organization based in Norwalk, Connecticut that establishes financial accounting and reporting standards for public and private companies and not-for-profit organizations that follow Generally Accepted Accounting Principles (GAAP)

${ }^{5}$ IASB, (2013) Leases: http://www.ifrs.org/Current-Projects/IASB-Projects/Leases/Pages/Leases.aspx
} 
capitalization of operating leasing on key financial ratios (Ashton, 1985, Imhoff, Lipe, \& Wright 1991, Beattie V. et al., 1998, Goodacre, 2003, Durocher, 2008, Jesswein, 2009, Grossman \& Grossman 2010, Singh, 2010, Fitò, Morgan \& Orgaz, 2013, Nuriani, Hengb, \& Jeliesta, 2015).

In the most recent study in 2008, Durocher developed and used a refined constructive capitalization method in which company-specific assumptions - interest rate, total, expired, remaining lives of leased assets and tax rate - were used to compute the impact of operating lease capitalization on key financial indicators for a sample of Canadian public companies. The results of this study indicated that capitalizing operating leases could increase the debt-to-asset ratio and decrease the current ratio significantly. These results were noted across all industry segments in the sample, whereas significant impacts on return on assets, return on equity and/or earnings per share were noted in only three industry segments: merchandising and lodging, oil and gas, and financial services (Durocher, 2008). Another study in 2008 in Germany (Fulbier, Pferdehirt, \& Silva, 2008) analysed the impact of operating lease capitalization for a sample of 90 companies belonging to the three major indices (DAX 30, MDAX and SDAX) for the years 2003 and 2004. The results show a considerable impact on companies, especially those in the fashion and retail industry.

The same study was undertaken by Jesswein in 2009. In an analysis of 595 U.S. companies, Jesswein detected the impact of the capitalization of operating leasing on key financial ratios, particularly on the current ratio, quick ratio, Altman ratio, interest coverage, EBITDA coverage, debt ratio and return on invested capital (those used to assess the credit standing of companies). The results indicate that nearly one-quarter of the companies that were considered relatively free of credit risk would not be considered this way if their operating leases were taken into account (Jesswein, 2009:83).

Another study (Grossman \& Grossman, 2010) took a sample of 91 nonfinancial companies from the top 200 of the Fortune 500 that had issued 2009 10-K reports to analyse the effect of including total operating lease payments on the current ratio and the ratio of total liabilities to total assets. The results show that in many companies of the sample, the current ratio and the ratio of total liabilities to total assets have worsened. This means that some companies are in violation of debt covenants, which require strict debt ratio (Grossman \& Grossman, 2010:11).

In 2010, Singh analysed the expected impact for a sample of 234 firms, including 64 restaurants and 170 retail firms, for the period $2006-2008$. He found significant relative and absolute differences across and within the two industries in relation to financial ratios related to leverage, profitability and interest coverage (Singh, 2010).

In 2015, Nuryani aimed to examine determinants of operating lease policies (financial constraint, asset value, growth and firm size) and the impact of constructive capitalization of operating leases towards a company's financial ratios. The finding shows that all determinants except financial constraints influence operating lease policies, although most operating leases are explained by factors other than economic determinants (Nuryani, et al., 2015).

\subsection{IFRS 16 Leases}

As mentioned previously, IFRS 16 is the result of a joint project initiated by the IASB together with the U.S. national standard setter, the FASB, to address concerns raised by users of financial statements with respect to reduced comparability between financial statements due to the very different accounting applied to operating and finance leases and limitations in the information provided on operating leases and on entities' exposure to risks arising from lease arrangements.

To address those concerns, the two boards decided to develop a new approach to lessee accounting that requires a lessee to recognize assets and liabilities for the rights and obligations created by leases (with some limited exceptions) and to enhance the required disclosures on leases.

IFRS 16 applies to all leases, including leases of right of use assets in a sublease, with the exception of specific items covered by other standards:

- leases to explore for or use minerals, oil, natural gas and similar non-regenerative resources;

- contracts within the scope of IFRIC 12 Service Concession Arrangements;

- for lessors, licenses of intellectual property within the scope of IFRS 15 Revenue from Contracts with customers;

- for lessees, leases of biological assets within the scope of IAS 41 Agriculture and rights held under licensing agreements within the scope of IAS 38 Intangible Assets for items such as motion picture films, video recordings, plays, manuscripts, patents and copyrights. 
In response to concerns raised over the cost of applying the requirements of the new standard, the IASB decided to provide some relief for prepares by allowing short-term leases and leases of low-value assets to be accounted for by recognizing an expense, typically straight-line, over the lease term.

IFRS 16 aims to distinguish a lease from a service contract based on whether a customer is able to control the asset being leased. A contract is, or contains, a lease if the contract provides a customer with the right to control the use of the identified asset for a period of time in exchange for consideration. Control is considered to exist if the customer has i) the right to obtain substantially all of the economic benefits from the use of an identified assets or ii) the right to direct the use of that asset. At the beginning of the contract, the lessee recognizes both the right of use of the asset and the lease liability on the balance sheet. The date of the initial lease recognition is defined as the date on which the lessor makes the leased asset available to the lessee (defined as the commencement date).

In measuring the right of use of the asset, the lessee is required to include the cost of such a right:

- the amount of the future liability measured in accordance with the lease agreement at the commencement date;

- any rental fees paid to the lessor at or before the commencement date, net of any possible incentives received from the lessor;

- possible initial direct costs incurred by the lessee;

- an estimate of the costs to be borne by the lessee in the event of dismantling and/or removal of the leased asset, restoring the site on which the asset is located or restoring the leased asset under the terms and conditions of the contract.

Subsequently, an entity will assess the right of use by means of the cost model or the revaluation model provided for by IAS 16, or, if the leased asset is a real estate investment, by the fair value model provided by IAS 40 .

Corresponding to the right of use recognized as an asset in the financial statements, there will be a financial liability. An entity must recognize a lease liability for the present value of future discounted lease payments at the lease rate implied in the lease agreement, if determinable. In the event an entity is unable to estimate the interest rate implied in the contract, the rate used will be the incremental borrowing rate of the entity.

Special attention must be paid to the definition of the term of the lease contract and the future lease payments of the contract. When there are options for extensions and/or termination of the contract that are exercisable at the sole discretion of the lessee and are considered "reasonably certain", they should be considered in the measurement of the lease liability (in an ordinary lease for a shop of 6 years renewable for another 6 years at the sole discretion of the lessee, it will be necessary to evaluate whether the contract term is 6 or 12 years). Conversely, the lessors' financial statements will be subject to limited changes with the introduction of IFRS 16 .

\subsection{Alternative Performance Measures}

In the international arena, there have been many discussions on metrics for measuring the performance of entities and how the entities show and calculate Alternative Performance Measures - APMs (e.g., EBITDA, adjusted EBITDA, EBIT, adjusted EBIT, and net financial position).

In 2005, the first recommendations on $\mathrm{APMs}^{6}$ (or non-GAAP measures) were made. Since then, several updates on accounting principles and professional standards have been provided; today, the regulatory agencies have realized the importance of updating APM regulations. In 2015, the European Securities and Markets Authority (ESMA) issued new guidelines (NGL) regarding APMs. The reason was that financial statements reflected data and other information according to applicable accounting standards, although entities use APMs not required by accounting principles to communicate financial information and results (Magli, Nobolo, \& Ogliari, 2017).

What are the most important APMs that include leases and therefore could benefit from their re-evaluation thanks to IFRS 16 ?

- $\boldsymbol{E B I T D A R}$ : This measure is defined as the total adjusted EBITDA plus rental expenses. This is an APM indicator commonly used by management to evaluate the financial performance and resource allocation for operating units within a company. These tools serve as measures of leverage capacity and debt serviceability. This APM is the relevant one to calculate a leverage ratio once capitalized operating

\footnotetext{
${ }^{6} \mathrm{An}$ APM is a financial measure of either historical or future financial performance, financial position or cash flow other than the items specified in the valid financial reporting framework.
} 
leases are added to financial debt. It is also useful for conducting cross-company comparisons when different capital structures are in place.

- Total Adjusted Financial Debt: This measure is the total net financial debt plus capitalized rental expenses at a 4.0x multiple, as per Moody's Investor Services methodology. This APM is used as a metric to assess a company's financial liabilities considering operating leases as debt, which is expected to be the case once IFRS 16 is implemented in 2019.

- Total Adjusted Net Financial Debt: This measure is the total adjusted financial debt, as defined above, minus cash and cash equivalents. This indicator is used to assess a company's financial liabilities, including operating leases and taking into account available cash.

IFRS 16 affects the operating results, financial results, financial debts and timing of charging costs in the income statement. In addition, in the presence of operating leases, it is a market practice to adjust the debt of companies during merger and acquisition transactions or when the rating agencies determine the rating of entities. IFRS 16 introduces one of the most important changes in the metrics of financial statements in that entities will have to re-think their APMs, and other stakeholders will have to adjust their models to evaluate the value and performance of entities.

\section{Methodology}

The method used in the study is both qualitative and quantitative as follows:

- the subject of the analysis is a new accounting standard (IFRS 16 will be effective 1 January 2019);

- it is necessary to study the potential impacts on previously approved financial statements to increase awareness of the entities on the possible range of impacts expected with the introduction of the new standard;

- it is not possible to quantify the potential effects coming from the application of the new standard without the assurance on the completeness of disclosures on future operating lease payments provided by issuers in accordance with IAS 17.

This study aims to provide preliminary insights about the magnitude of the potential impacts of IFRS 16 on the various business sectors of Italian issuers; in particular, the study analyses and estimates the following aspects:

- amount of rights of use on total assets recognized in the financial statements;

- information that will be available to users of financial statements to perform a prospective cash flow analysis;

- impacts on capital position and the financial condition of the entity;

- impacts on profitability and performance metrics of the entity;

- effects on the quality of financial information and the comparability of financial statements.

\subsection{Sample and Source of Data}

We developed a property database composed of secondary data and consistent with the purpose of our study. We decided to gather quantitative data from annual reports, an approach that is both objective, being based on official information, and practical, as it would have been difficult to use questionnaires to gather an extensive amount of precise information from a large sample of firms.

The information used in the study was obtained from the financial statements published by entities listed in Italy (in the case of groups, the consolidated financial statement was used). We analysed the financial statements of 384 issuers and identified 113 issuers that disclose information on future committed payments. We prepared a checklist and then we analysed the financial statements of issuers. First, we identified the issuers that have operating leases. Second, we focused on issuers that use operating lease and we did an in-depth analysis of the use of operating leases. Finally, we estimated the effects of the application of IFRS 16. In particular, the quantitative data from annual reports that we use in our analysis are:

- future committed payments of operating leases in accordance with IAS 17;

- revenues;

- EBITDA;

- total assets;

- financial indebtedness; 
- equity;

- annual operating lease payments.

In the course of the study, a check of the completeness and accuracy of the public information used was not performed.

\subsection{Assumptions Used}

The estimated potential effects arising from the adoption of IFRS 16 are purely indicative and have been made using certain various assumptions. As a result, their actual impacts upon adoption may be different, and the estimates are subject to certain limitations.

The information contained in the study should be read by taking the following into consideration:

- sector information is based on the classification proposed by the info providers;

- the analysis was performed using information provided in the entities' financial statements as of 31 December 2016;

- data were analysed in Euros;

- future discounted minimum leases payments were estimated using a discount rate of 5\%;

- EBITDA is an APM and has been used without any verification of the calculation method;

- a significant number of entities remain excluded from the analysis due to the absence of disclosures on operating leases in the notes to the financial statements.

\section{Impacts of the Application of IFRS 16 on Listed Issuers Financial Statements}

This study aims to estimate the impacts arising from the introduction of IFRS 16 on the financial statements of Italian-listed issuers. In particular, the study analyses the following aspects on the basis of the statement of financial position as of 31 December 2016, and the information disclosed in the notes to the financial statements is as follows:

- the amount of the rights of use on total assets recognized in the financial statements;

- the information that will be available to the users of the financial statement to perform a prospective cash flow analysis;

- the impacts on profitability and the performance of entities;

- the impacts on the financial position of entities.

The population surveyed is represented by 384 issuers whose shares are traded on the markets managed by the Italian Stock Exchange. The estimate of the potential impacts on the financial statements from the adoption of IFRS 16 was based on an analysis of the notes to the financial statements for the year ending on 31 December 2016 of the issuers claiming to make use of operating leases. The study was performed using certain assumptions as detailed in paragraph 3.2. Table 1 shows the composition of entities providing disclosures on future lease payments in the notes to the financial statements.

Table 1. Percentage of entities with disclosures relating to operating leases in the notes to the financial statement

\begin{tabular}{cc}
\hline & \\
Euros $000,000,000$ & $5 \%$ \\
FTSE AIM Italia & $77 \%$ \\
FTSE ALL Share & $11 \%$ \\
FTSE Italia Micro Cap & $33 \%$ \\
FTSE Italia Mid Cap & $12 \%$ \\
FTSE Italia Small Cap & $34 \%$ \\
FTSE Italia Star & $60 \%$ \\
FTSE MIB & $48 \%$ \\
OTHER (*) & Euro 173.6 billion \\
Total future undiscounted lease payments & Euro 131.9 billion \\
\hline
\end{tabular}

(*) listed entities on multiple stock segments

As mentioned, this study covered the 2016 financial statements of 384 issuers, of which only 113 reported disclosures on operating leases in the notes to the financial statements. This aspect might represent a limitation to the present study.

The total amount of future payments related to operating leases was estimated to be $€ 173.6$ billion (undiscounted). The discounted value of these future payments was estimated to be $€ 131.9$ billion (using a 
conventional 5\% discount rate), representing $76 \%$ of future undiscounted lease payments disclosed in the notes to the financial statements.

This study then focused on the disclosures reported in the 2016 financial statements of the aforementioned 113 entities. Table 2 shows the details of future discounted minimum lease payments segregated by the different markets managed by the Italian Stock Exchange.

Table 2. Future discounted minimum lease payments separated by market

\begin{tabular}{cc}
\hline Euros 000,000,000 & \\
\hline FTSE AIM Italia & 0.23 \\
FTSE ALL Share & 30.17 \\
FTSE Italia Micro Cap & 0.03 \\
FTSE Italia Mid Cap & 2.74 \\
FTSE Italia Small Cap & 0.39 \\
FTSE Italia STAR & 0.84 \\
FTSE MIB & 28.42 \\
OTHER (*) & 69.10 \\
Total future discounted minimum lease payments & Euro $\mathbf{1 3 1 . 9}$ billion \\
(estimated value) & \\
\hline
\end{tabular}

\section{(*) listed entities on multiple stock segments}

This study shows that commitments for future payments of operating leases disclosed in the notes to the financial statements and consequently the potential impacts of IFRS 16 can be very different depending on the business sector to which the entity belongs. The ratio between future minimum lease payments and total assets is considered an indicator of impacts that IFRS 16 will have on financial statements because the entities do not record the amount in the financial statements when using IAS 17, while they record the amounts of lease payments as financial liabilities in their financial statements when using IFRS 16. Thus, a high ratio is an indicator that IFRS 16 will have relevant effects on the main financial statements metrics. Table 3 shows a breakdown by business sector of the future minimum lease payments compared to the issuer's assets.

Table 3. Ratio between future minimum lease payments and total assets

\begin{tabular}{|c|c|c|c|c|c|c|}
\hline Euros 000,000,000 & $\begin{array}{l}\mathbf{N}^{\circ} \text { of } \\
\text { entities }\end{array}$ & $\begin{array}{l}\text { Total } \\
\text { assets }\end{array}$ & $\begin{array}{c}\text { Future } \\
\text { undiscounted } \\
\text { payments for } \\
\text { operating } \\
\text { leases }\end{array}$ & $\begin{array}{c}\text { Ratio } \\
\text { between } \\
\text { future lease } \\
\text { payments } \\
\text { and total } \\
\text { assets }\end{array}$ & $\begin{array}{c}\text { Future } \\
\text { discounted } \\
\text { lease } \\
\text { payments }\end{array}$ & $\begin{array}{c}\text { Ratio } \\
\text { between } \\
\text { future } \\
\text { discounted } \\
\text { lease } \\
\text { payments and } \\
\text { total assets }\end{array}$ \\
\hline $\begin{array}{l}\text { Aerospace, defence, } \\
\text { airlines, and transport }\end{array}$ & 7 & 363.7 & 16.8 & $4.6 \%$ & 12.8 & $3.5 \%$ \\
\hline Automotive & 5 & 708.1 & 27.7 & $3.9 \%$ & 21.1 & $3.0 \%$ \\
\hline Banking & 11 & 6.027 .5 & 34.2 & $0.6 \%$ & 26.0 & $0.4 \%$ \\
\hline Chemical & 7 & 214.6 & 7.1 & $3.3 \%$ & 5.4 & $2.5 \%$ \\
\hline Consumer products & 21 & 636.4 & 13.5 & $2.1 \%$ & 10.3 & $1.6 \%$ \\
\hline Energy \& utilities & 10 & 481.8 & 8.3 & $1.7 \%$ & 6.3 & $1.3 \%$ \\
\hline Industrial products & 17 & 437.9 & 2.8 & $0.6 \%$ & 2.1 & $0.5 \%$ \\
\hline Investment management & 9 & $1,440.9$ & 7.2 & $0.5 \%$ & 5.4 & $0.4 \%$ \\
\hline Real estate & 3 & 25.3 & 0.9 & $3.6 \%$ & 0.7 & $2.7 \%$ \\
\hline Retailer & 5 & 84.6 & 13.7 & $16.2 \%$ & 10.4 & $12.3 \%$ \\
\hline Technology & 10 & 214.1 & 6.5 & $3.0 \%$ & 5.0 & $2.3 \%$ \\
\hline Telecommunication & 4 & 310.8 & 31.5 & $10.1 \%$ & 23.9 & $7.7 \%$ \\
\hline Other sectors & 4 & 46.2 & 3.4 & $7.4 \%$ & 2.6 & $5.6 \%$ \\
\hline Total & 113 & $10,991.9$ & 173.6 & $4.4 \%$ & 131.9 & $3.4 \%$ \\
\hline $\begin{array}{l}\text { Total (excluding banking } \\
\text { sector) }\end{array}$ & 102 & $4,964.4$ & 139.3 & $4.8 \%$ & 105.9 & $3.6 \%$ \\
\hline
\end{tabular}

It is clear that operating leases are concentrated in certain business sectors, although there may be a dispersion of values within each sector. As shown in the table above, the business sectors with higher use of future lease payments include the retailer $(16.2 \%)$ and telecommunication $(10.1 \%)$ sectors.

This study shows that the average ratio between future undiscounted minimum lease payments and total assets of the analysed entities is $4.8 \%$ (excluding the banking sector), while the average future discounted minimum lease payments represent $3.6 \%$ of the entities' assets (excluding the banking sector). An aggregate analysis for some business sectors shows that the ratio between future minimum lease payment and total assets exceeds $5 \%$ of total assets. 
It should also be noted that the amount of future minimum lease payments for individual entities belonging to a business sector might be very different from the average value due to the abovementioned dispersion of values within the sectors. The results of analysis are in line with expectations as the retailer and telecommunication sectors use the operating lease extensively.

Table 4 details the breakdown of entities belonging to different business sectors. For example, $10 \%$ of entities providing disclosures on operating leases (11 out of 113 entities) have an estimated future minimum lease payments and total assets ratio between $20 \%$ and $50 \%$, which is higher than the total average of $3.4 \%$. However, $25 \%$ of telecommunication companies ( 1 out of 4 companies in the sector) have an estimated future minimum lease payments and total assets ratio between $10 \%$ and $20 \%$, which is higher than the industry average of $7.7 \%$.

Table 4. Analysis of the ratio between future discounted minimum lease payments and total assets

\begin{tabular}{|c|c|c|c|c|c|c|c|c|c|}
\hline Business sectors & & $<1 \%$ & $1-5 \%$ & $\begin{array}{c}5- \\
10 \%\end{array}$ & $\begin{array}{l}10- \\
20 \%\end{array}$ & $\begin{array}{l}\mathbf{2 0}- \\
\mathbf{5 0 \%}\end{array}$ & $\begin{array}{r}50- \\
100 \%\end{array}$ & $>100 \%$ & Total \\
\hline $\begin{array}{l}\text { Aerospace, defence, } \\
\text { airlines, and transport }\end{array}$ & $3.5 \%$ & $\begin{array}{c}3- \\
43 \%\end{array}$ & $\begin{array}{c}1- \\
14 \%\end{array}$ & $\begin{array}{c}3- \\
43 \%\end{array}$ & - & - & - & - & $\begin{array}{c}7- \\
100 \%\end{array}$ \\
\hline Automotive & $3.0 \%$ & $\begin{array}{c}1- \\
20 \%\end{array}$ & $\begin{array}{l}3- \\
60 \%\end{array}$ & $\begin{array}{c}1- \\
20 \%\end{array}$ & - & - & - & - & $\begin{array}{c}5- \\
100 \%\end{array}$ \\
\hline Banking & $0.4 \%$ & $\begin{array}{c}8- \\
73 \%\end{array}$ & $\begin{array}{c}2- \\
18 \%\end{array}$ & - & - & $1-9 \%$ & - & - & $\begin{array}{l}11- \\
100 \%\end{array}$ \\
\hline Chemical & $2.5 \%$ & $\begin{array}{c}2- \\
29 \%\end{array}$ & $\begin{array}{c}4- \\
57 \%\end{array}$ & - & $1-14 \%$ & - & - & - & $\begin{array}{c}7- \\
100 \%\end{array}$ \\
\hline$\underline{\text { Consumer products }}$ & $1.6 \%$ & $\begin{array}{c}4- \\
19 \%\end{array}$ & $\begin{array}{c}5- \\
24 \%\end{array}$ & $\begin{array}{l}2- \\
10 \%\end{array}$ & $4-19 \%$ & $5-24 \%$ & $1-5 \%$ & - & $\begin{array}{l}21- \\
100 \%\end{array}$ \\
\hline Energy \& utilities & $1.3 \%$ & $\begin{array}{c}4- \\
40 \%\end{array}$ & $\begin{array}{c}5- \\
50 \%\end{array}$ & - & $1-10 \%$ & - & - & - & $\begin{array}{l}10- \\
100 \%\end{array}$ \\
\hline Industrial products & $0.5 \%$ & $\begin{array}{c}5- \\
29 \%\end{array}$ & $\begin{array}{l}7- \\
41 \%\end{array}$ & $4-24 \%$ & $1-6 \%$ & - & - & - & $\begin{array}{l}17- \\
100 \%\end{array}$ \\
\hline$\frac{\text { Investment }}{\text { management }}$ & $0.4 \%$ & $\begin{array}{c}3- \\
33 \%\end{array}$ & $\begin{array}{c}5- \\
56 \%\end{array}$ & - & - & $1-11 \%$ & - & - & $\begin{array}{c}9- \\
100 \%\end{array}$ \\
\hline$\underline{\text { Real estate }}$ & $2.7 \%$ & - & $\begin{array}{c}3- \\
100 \%\end{array}$ & - & - & - & - & - & $\begin{array}{c}3- \\
100 \%\end{array}$ \\
\hline$\underline{\text { Retailer }}$ & $12.3 \%$ & - & - & $\begin{array}{l}3- \\
60 \%\end{array}$ & - & $1-20 \%$ & - & $1-20 \%$ & $\begin{array}{c}5- \\
100 \%\end{array}$ \\
\hline$\underline{\text { Technology }}$ & $2.3 \%$ & - & $\begin{array}{c}6- \\
60 \%\end{array}$ & $\begin{array}{c}2- \\
20 \%\end{array}$ & $1-10 \%$ & $1-10 \%$ & - & - & $\begin{array}{l}10- \\
100 \%\end{array}$ \\
\hline$\underline{\text { Telecommunication }}$ & $7.7 \%$ & - & - & $\begin{array}{l}3- \\
75 \%\end{array}$ & $1-25 \%$ & - & - & - & $\begin{array}{c}4- \\
100 \%\end{array}$ \\
\hline Other sectors & $5.6 \%$ & $\begin{array}{c}1- \\
25 \%\end{array}$ & - & $\begin{array}{c}1- \\
25 \%\end{array}$ & - & $2-50 \%$ & - & - & $\begin{array}{c}4- \\
100 \%\end{array}$ \\
\hline Total & $3.4 \%$ & $\begin{array}{l}31- \\
27 \%\end{array}$ & $\begin{array}{l}41- \\
36 \%\end{array}$ & $\begin{array}{l}19- \\
17 \%\end{array}$ & $9-8 \%$ & $11-10 \%$ & $1-1 \%$ & $1-1 \%$ & $\begin{array}{l}113- \\
100 \%\end{array}$ \\
\hline
\end{tabular}

\subsection{Effects on Entities Performance}

IFRS 16 requires an initial recognition of the so-called "right of use" of the assets and a corresponding financial debt for all leases (without any distinction between operating and finance leases). Subsequently, the right of use of the asset will be depreciated, and financial debt will be measured using the amortized cost method provided by IAS 39 (thus charging the related financial charges in the income statement). Currently, IAS 17 requires the recognition of assets for only finance leases, while operating lease costs are recognized on a straight-line basis in the income statement over the term of the contract. As mentioned before, when the lessees record the operating leasing using IAS 17, entities record only the fee on an accrual basis in their EBITDA without impacts on financial statement position. Using IFRS 16, the lessees record the lease in a different way. In particular, entities must record all leases in the financial statement position (assets and financial liabilities) with an exemption for only low-value and short-term leases. Entities must record the lease in the income statement on different lines: i) low-value and short-term leases in EBITDA; ii) the amortization of the right of use in EBIT; and iii) interest related to financial debts in the interest charges. In addition, entities will have a temporary effect on income net results. Using IFRS 16 requirements, the entities must record the amortization of the right of use on a straight-line basis and the interest charges related to financial debts. Therefore, entities record the amortization plus the interest charge on debt, and the interest charge decreases as the financial debt decreases. Thus, using IAS 17, entities record the cost of operating leasing along with the contractual period; using IFRS 16, entities record a higher cost in the first part of the contract and a lower cost in the second part of the contract.

The application of IFRS 16 will generally have the following effects on the income statement of entities with 
operating leases over the duration of the agreement:

- Increase in EBITDA (due to the absence of operating lease payments reported as "service costs" and, therefore, above EBITDA);

- Increase in EBIT (due to the absence of operating lease payments, which is partially offset by the depreciation of the right of use of assets);

- Increase in financial charges (arising from the adoption of the amortized cost method to finance lease debt);

- No effects on net results over the entire contract term.

There will be no effect on net profits over the length of the entire contract. However, when adopting the new standard, more costs will be recognized in the first few years of a contract because higher financial charges are recorded in the first years and lower charges in the latter years of agreements through the amortized cost method (only variable lease payments and fees for leases of low-value assets will be recognized as components of EBITDA).

Table 5 shows EBITDA of the entities under review and their EBITDA/revenues ratio. It also shows an estimate of EBITDA and the new EBITDA/revenue ratio if all leases were recorded as required by IFRS 16. This study does not consider the banking sector because EBITDA is not considered a relevant indicator of sector performance; the banking sector uses another APM to monitor its performance.

Table 5. EBITDA/revenues for IAS 17 and IFRS 16

\begin{tabular}{|c|c|c|c|c|c|}
\hline \multirow{2}{*}{$\begin{array}{l}\text { Business sectors } \\
\text { In Euro } 000,000\end{array}$} & \multicolumn{2}{|c|}{ EBITDA } & \multicolumn{2}{|c|}{ EBITDA/revenues } & \multirow{2}{*}{$\begin{array}{c}\text { EBITDA } \\
\text { increase IFRS } \\
16 \text { vs IAS } 17\end{array}$} \\
\hline & $\begin{array}{l}\text { IAS 17 } \\
\text { (actual) }\end{array}$ & $\begin{array}{l}\text { Applying IFRS } \\
16 \text { (estimate) }\end{array}$ & $\begin{array}{l}\text { IAS 17 } \\
\text { (actual) }\end{array}$ & $\begin{array}{l}\text { Applying IFRS } \\
16 \text { (estimate) }\end{array}$ & \\
\hline $\begin{array}{l}\text { Aerospace, defence, } \\
\text { airlines, and transport }\end{array}$ & 23.318 & 30.011 & $10 \%$ & $13 \%$ & $29 \%$ \\
\hline Automotive & 39.226 & 49.357 & $9 \%$ & $12 \%$ & $26 \%$ \\
\hline Banking & n.a. & n.a & n.a. & n.a. & n.a. \\
\hline $\begin{array}{l}\text { Chemical } \\
\text { Consumer products }\end{array}$ & $\begin{array}{l}34.124 \\
55.956\end{array}$ & $\begin{array}{l}35.611 \\
80.448\end{array}$ & $\begin{array}{l}24 \% \\
7 \%\end{array}$ & $\begin{array}{l}25 \% \\
10 \%\end{array}$ & $\begin{array}{c}4 \% \\
44 \%\end{array}$ \\
\hline Energy \& utilities & 43.760 & 45.120 & $18 \%$ & $18 \%$ & $3 \%$ \\
\hline Industrial products & 10.211 & 11.008 & $14 \%$ & $15 \%$ & $8 \%$ \\
\hline Investment management & 13.581 & 14.212 & $5 \%$ & $5 \%$ & $5 \%$ \\
\hline Real estate & 1.545 & 1.706 & $9 \%$ & $10 \%$ & $10 \%$ \\
\hline Retailer & 21.769 & 24.300 & $16 \%$ & $18 \%$ & $12 \%$ \\
\hline Technology & 28.388 & 29.031 & $21 \%$ & $21 \%$ & $2 \%$ \\
\hline Telecommunication & 42.441 & 44.097 & $32 \%$ & $33 \%$ & $4 \%$ \\
\hline Other sectors & 4.275 & 4.985 & $10 \%$ & $12 \%$ & $17 \%$ \\
\hline Total & 318.593 & 369.887 & $15 \%$ & $16 \%$ & $14 \%$ \\
\hline
\end{tabular}

The analysis estimates that IFRS 16 will improve the EBITDA/revenue ratio and will result in an EBITDA improvement from $15 \%$ to $16 \%$ for the average of analysed entities; the EBITDA increase in absolute terms is estimated to be $14 \%$. The impact of the application of IFRS 16 will be different depending on the use of operating lease contracts among the different business sectors.

Table 6 shows the distribution of entities belonging to different business sectors. For example, 35\% of industrial products companies (6 out of 17) reported an increase higher than $10 \%$ in the estimated EBITDA compared to the current one, with an $8 \%$ industry average. Moreover, $29 \%$ of entities operating in aerospace, defence, airlines, and transport ( 2 out of 7) reported an increase in the estimated EBITDA between $1 \%$ and $5 \%$ compared to the current one, which is smaller than the $29 \%$ industry average. 
Table 6. EBITDA/revenue analysis for IAS 17 and IFRS 16

\begin{tabular}{|c|c|c|c|c|c|c|}
\hline Business sector & & $<1 \%$ & $1-5 \%$ & $5-10 \%$ & $>10 \%$ & Total \\
\hline $\begin{array}{l}\text { Aerospace, defence, airlines, } \\
\text { and transport }\end{array}$ & $29 \%$ & - & $2-29 \%$ & $2-29 \%$ & $3-43 \%$ & $7-100 \%$ \\
\hline $\begin{array}{l}\text { Automotive } \\
\text { Banking }\end{array}$ & $26 \%$ & - & $2-40 \%$ & $\begin{array}{l}2-40 \% \\
\text { n.a. }\end{array}$ & $1-20 \%$ & $5-100 \%$ \\
\hline Chemical & $4 \%$ & $2-29 \%$ & $3-43 \%$ & $1-14 \%$ & $1-14 \%$ & $7-100 \%$ \\
\hline Consumer products & $44 \%$ & $3-14 \%$ & $5-24 \%$ & $6-29 \%$ & $7-33 \%$ & $21-100 \%$ \\
\hline Energy \& utilities & $3 \%$ & $3-30 \%$ & $2-20 \%$ & $4-40 \%$ & $1-10 \%$ & $10-100 \%$ \\
\hline Industrial products & $8 \%$ & $1-6 \%$ & $6-35 \%$ & $4-24 \%$ & $6-35 \%$ & $17-100 \%$ \\
\hline Investment management & $5 \%$ & $1-11 \%$ & $8-89 \%$ & - & - & $9-100 \%$ \\
\hline Real estate & $10 \%$ & - & $1-33 \%$ & $1-33 \%$ & $1-33 \%$ & $3-100 \%$ \\
\hline Retailer & $12 \%$ & - & - & $2-40 \%$ & $3-60 \%$ & $5-100 \%$ \\
\hline Technology & $2 \%$ & $1-10 \%$ & $2-20 \%$ & $1-10 \%$ & $6-60 \%$ & $10-100 \%$ \\
\hline Telecommunication & $4 \%$ & - & $2-50 \%$ & $1-25 \%$ & $1-25 \%$ & $4-100 \%$ \\
\hline Other sectors & $17 \%$ & - & $1-25 \%$ & - & $3-75 \%$ & $4-100 \%$ \\
\hline Total & $14 \%$ & $11-11 \%$ & $34-33 \%$ & $24-24 \%$ & $33-32 \%$ & $100 \%$ \\
\hline
\end{tabular}

4.2 The Impact on the Net Financial Position

As previously mentioned, IFRS 16 requires the recognition of the right of use of assets and the corresponding financial debt. The current IAS 17 requires the recognition of assets for only finance leases. The adoption of IFRS 16 will generally have the following impacts to the financial position of entities with operating leases:

- an increase in the assets recognized in the statement of financial position;

- an increase in financial indebtedness.

Table 7. Ratio between long-term debts and equity

\begin{tabular}{|c|c|c|c|c|c|c|c|}
\hline \multirow{2}{*}{$\begin{array}{l}\text { In Euro 000,000 } \\
\text { Business sectors }\end{array}$} & \multicolumn{4}{|c|}{ Financial indebtedness } & \multicolumn{3}{|c|}{ Indebtedness/equity } \\
\hline & $\begin{array}{ll}\text { IAS } & 17 \\
\text { (actual) }\end{array}$ & $\begin{array}{l}\text { IFRS 16 } \\
\text { (estimate) }\end{array}$ & Var \% & $\begin{array}{l}\text { Adjusted } \\
\text { debt (annual } \\
\text { fees } x \text { 8) }\end{array}$ & $\begin{array}{l}\text { IAS 17 } \\
\text { (actual) }\end{array}$ & $\begin{array}{l}\text { IFRS 16 } \\
\text { (estimate) }\end{array}$ & $\begin{array}{l}\text { Adjusted } \\
\text { debt } \\
\text { (annual } \\
\text { fees x8) }\end{array}$ \\
\hline $\begin{array}{l}\text { Aerospace, defence, } \\
\text { airlines, and transport }\end{array}$ & 100,348 & 117,130 & $17 \%$ & 119,120 & $103 \%$ & $120 \%$ & $123 \%$ \\
\hline $\begin{array}{l}\text { Automotive } \\
\text { Banking }\end{array}$ & 53,486 & 81,199 & $52 \%$ & 84,486 & $33 \%$ & $50 \%$ & $52 \%$ \\
\hline $\begin{array}{l}\text { Banking } \\
\text { Chemical }\end{array}$ & 22234 & 29344 & $32 \%$ & $\begin{array}{r}\text { n.a. } \\
30187\end{array}$ & $360 \%$ & $47 \%$ & 100 \\
\hline Consumer products & 140,317 & 153,804 & $10 \%$ & 155,404 & $\begin{array}{l}50 \% \\
72 \%\end{array}$ & $79 \%$ & $80 \%$ \\
\hline Energy \& utilities & 97,315 & 105,590 & $9 \%$ & 106,572 & $57 \%$ & $62 \%$ & $62 \%$ \\
\hline Industrial products & 27,955 & 30,717 & $10 \%$ & 31,045 & $88 \%$ & $97 \%$ & $98 \%$ \\
\hline $\begin{array}{l}\text { Investment } \\
\text { management }\end{array}$ & 5,522 & 12,685 & $130 \%$ & 13,534 & $6 \%$ & $13 \%$ & $14 \%$ \\
\hline Real estate & 2,242 & 3,149 & $40 \%$ & 3,257 & $33 \%$ & $47 \%$ & $48 \%$ \\
\hline Retailer & 8,603 & 22,298 & $159 \%$ & 23,923 & $31 \%$ & $80 \%$ & $86 \%$ \\
\hline Technology & 31,926 & 38,453 & $20 \%$ & 39,228 & $32 \%$ & $38 \%$ & $39 \%$ \\
\hline Telecommunication & 100,392 & 131,866 & $31 \%$ & 135,600 & $103 \%$ & $136 \%$ & $39 \%$ \\
\hline Other sectors & 6,235 & 9,666 & $55 \%$ & 10,073 & $103 \%$ & $136 \%$ & $140 \%$ \\
\hline Total & 596,573 & 735,900 & $23 \%$ & 752,429 & $52 \%$ & $68 \%$ & $70 \%$ \\
\hline
\end{tabular}

For the analysed entities, Table 7 shows the following:

- financial indebtedness shown in the financial statements on 31 December 2016;

- estimated increase in medium- and long-term debt arising from the application of IFRS 16 (on the basis of the disclosures provided and related to operating lease payments in the notes to the financial statements) and the related percentage increase;

- $\quad$ estimate of medium- and long-term debts "adjusted" by analysts to include the impact of lease payments in evaluating the net financial position of the entity (from market practice, the adjustment is calculated multiplying by 8 the annual operating lease payments);

- ratio between long-term debts and equity using the following:

- actual data in the 2016 financial statements;

- the estimated medium- and long-term debt arising from the application of IFRS 16;

- the estimated medium- and long-term debt adjusted by market analysts according to market practice. 
Considering the fact that this parameter does not appear to be significant for the banking sector, the analysis was not performed.

\section{Conclusions}

This study shows that IFRS 16 will have a significant impact on the financial statements of lessees in terms of both the financial position and economic performance in certain business sectors. This research estimates the impacts that the new standard could have on balance sheets and income statements. In particular, on balance sheets, there will be an increase in lease assets, an increase in financial liabilities and a decrease in equity; on income statements, there will be an increase in EBITDA and an increase in finance costs.

This study estimates that in 2016, the discounted minimum lease payments for listed companies were 131.9 billion and that the sectors retailer and telecommunication had significant use of operating leases. The performance will be significantly affected by the changes introduced by IFRS 16 . On the one hand, the operating results will increase the EBITDA/revenues ratio, which will increase from $15 \%$ to $16 \%$, with EBITDA increasing by $14 \%$ using IFRS 16 compared with IAS 17 . On the other hand, financial metrics will be significantly affected by IFRS 16 . This research estimates that debts will increase by $23 \%$ and that the ratio debt/equity will increase from 52\%, using IAS 17, to 58\%, using IFRS 16 . Another important result identified in this study is that the market participants generally overstate the estimates related to the debt for operating leases. The rating agencies typically estimate the debt related operating leases multiplying the instalments recorded in the income statement by 8 ; thus, they would estimate the debt/equity ratio using IFRS 16 to be $70 \%$, while this research estimates the ratio to be $68 \%$.

Entities will have to accurately determine the impacts of the new standard and pay particular attention to the following aspects:

- the impact on finance covenants;

- communications with the market;

- the impact on the cost of debt;

- the impact on capital, financial and economic metrics;

- the changes needed in the information systems in order to manage the new lease accounting in accordance with the new standard.

Conversely, it is assumed that the new accounting model will allow for better financial statement comparability and a better evaluation of entities' financial position.

We believe that IFRS 16 will impact some of the main KPIs and APMs of entities; thus, we expect that entities will update their tools to communicate to market their performances. We expect that IFRS 16 could affect the models used by analysts in the valuations of entities.

The main contributions to the literatures are the estimate of the impacts of the new IFRS 16 on the different sectors, the identification of impacts on APMs and start a debate on how this new accounting standard could affect the company valuations.

As we have already summarized the main conclusions of our research, we end with three specific suggestions (or themes) for future research regarding the evolution of financial statements.

First, in terms of the impacts on models and APMs/KPIs, new studies could exploit how entities will change their APMs/KPIs and how market participants will update their entity valuation models.

Second, in terms of the costs and benefits of new rules, new studies could exploit the costs incurred by entities to apply the new standard and the benefit that it should generate.

Third, in terms of the impacts on models and transactions, new studies could exploit how market participants will update their entity valuation models and if transaction prices will be affected by new performance metrics.

\section{References}

Ashton, R. K. (1985). Accounting for Finance Leases: A Field Test. Accounting and Business Research, 15(59), 233-238. https://doi.org/10.1080/00014788.1985.9729269

Ball, R. (2006). International financial reporting standards (IFRS): pros and cons for investors. Accounting and Business Research, 36, 5-27. https://doi.org/10.1080/00014788.2006.9730040

Barone, E., Birt, J., \& Moya, S. (2014). Lease Accounting: A Review of Recent Literature. Accounting in Europe, 11(1), 35-54. https://doi.org/10.1080/17449480.2014.903630 
Beattie, V., Edwards, K., \& Goodacre A. (1998). The impact of constructive operating lease capitalization on key accounting rations. Accounting and Business Research, 28(4), 233-254. https://doi.org/10.1080/00014788.1998.9728913

Bowman, R. G. (1980). The debt equivalence of leases: an empirical investigation. Accounting Review, 55(2), 237-253.

Brown, P. (2011). International Financial Reporting Standards: what are the benefits? Accounting and Business Research, 41(3), 269-285. https://doi.org/10.1080/00014788.2011.569054

Durocher, S. (2008). Canadian evidence on the constructive capitalisation of operating leases. Accounting Perspectives, 7(3), 227-256. https://doi.org/10.1506/ap.7.3.2 Cited by: 16

Fitò, M. A., Moya, S., \& Orgaz, N. (2013). Considering the effects of operating lease capitalisation on key financial ratios. Revista Espanola de financiacion y contabilidad (Spanish Journal of Finance and Accounting), 159, 341-368. https://doi.org/10.1080/02102412.2013.10779750

Fulbier, R.U., Pferdehirt, M. H., \& Silva, J. L. (2008). Impact of Lease Capitalization on Financial Ratios of Listed German Companies. SSRN Electronic Journal, 60(2), 122-144. https://doi.org/10.1007/BF03396762

Goodacre, A. (2003). Operating lease finance in the UK retail sector. The International Review of Retail, Distribution and Consumer Research, 13(1), 99-125. https://doi.org/10.1080/0959396032000065373

Grossman, A. M., \& Grossman, S. D. (2010). Capitalizing lease payments. Potential effects of the FASB/IASB Plan. The CPA Journal, May 2010, 1-11.

IASB. (2013). Conceptual Framework. Retrieved 2013, from IFRS Foundation and the IASB: http://www.ifrs.org/current-projects/iasbprojects/conceptual-framework/discussion-paper-july-2013/docume nts/discussion-paper-conceptual-framework-july-2013.pdf

Imhoff, E. A., Lipe, R., \& Wright, D. (1991). Operating leases: Impact of constructive capitalization. Accounting Horizons, 5(1), 51-63. https://doi.org/10.1016/j.sbspro.2015.11.034

Jensen, M. C., \& Meckling, W. H. (1976). Theory of the firm: Managerial behavior, agency costs and ownership structure. Journal of Financial Economics, 3(4), 305-360. https://doi.org/10.1016/0304-405X(76)90026-X

Jesswein, K. R. (2009). Analyzing creditworthiness from financial statements in the presence of operating leases. Academy of Accounting and Financial Studies Journal, 13(1), 75-90. ISSN 1096-3685

Magli, F., Nobolo, A., \& Ogliari, M. (2017). Alternative Performance Measures and ESMA Guidelines: Improving Stakeholders' Communication. International Journal of Business and Management, 12(12), 15-28. https://doi.org/10.5539/ijbm.v12n12p15

Meeks, G., \& Meeks, J. G. T. (2001). Towards a Cost - Benefit analysis of accounting regulation. Institute of Chartered Accountants in England and Wales

Monson, D.W. (2001). The conceptual Framework and Accounting for Leases. Accounting horizons, 15(3), 275-287. https://doi.org/10.2308/acch.2001.15.3.275

Nuryani, N., Hengb, T. T., \& Juliesta, N. (2015). Capitalization of Operating Lease and Its Impact on Firm's Financial Ratios. Social and Behavioral sciences, 211, 268-276. https://doi.org/10.1016/j.sbspro.2015.11.034

Ro, B. T. (1978). The disclosure of Capitalized lease information \& the stock prices. Journal of Accounting Research, 16(2), 315-340. https://doi.org/10.2307/2490570

Singh, A. (2010). Proposed lease accounting changes: implications for the restaurant and retail industries, Journal of Hospitality \& Tourism Research, 36(3), 335-365. https://doi.org/10.1177/1096348010388659

Wang, S. (2013). Financial Communications. Information processing, media integration and ethical considerations, Palgrave Macmillan. https://doi.org/10.1057/9781137351876

Watts, R. L., \& Zimmerman, J. L. (1978). Towards a Positive Theory of the determination of accounting standards. The Accounting Review, LIII(1), 112-134.

Watts, R. L., \& Zimmerman, J. L. (1979). The demand for and supply of accounting theories: the market for excuses. The Accounting Review, LIV(2), 273-305.

Watts, R. L., \& Zimmerman, J. L. (1986). Positive accounting theory, Englewood Cliffs, NJ: Prentice-Hall.

\section{Copyrights}

Copyright for this article is retained by the author(s), with first publication rights granted to the journal.

This is an open-access article distributed under the terms and conditions of the Creative Commons Attribution license (http://creativecommons.org/licenses/by/4.0/). 